\title{
Tillage Effects on Spatiotemporal Variability of Particulate Organic Matter
}

\author{
Juhwan Lee, ${ }^{1}$ Emilio A. Laca, ${ }^{1}$ Chris van Kessel, ${ }^{1}$ Dennis E. Rolston, ${ }^{2}$ \\ Jan W. Hopmans, ${ }^{2}$ and Johan Six ${ }^{1}$ \\ ${ }^{1}$ Department of Plant Sciences, University of California, Davis, CA 95616, USA \\ ${ }^{2}$ Department of Land, Air and Water Resources, University of California, Davis, CA 95616, USA
}

Correspondence should be addressed to Juhwan Lee, ecolee@ucdavis.edu

Received 19 December 2008; Revised 29 April 2009; Accepted 20 August 2009

Recommended by Oliver Dilly

This study was performed to evaluate effects of no-till (NT) and standard tillage (ST) on POM in two 15-ha neighboring fields from 2003 to 2004. We also evaluated the effects of minimum tillage (MT) on POM after both NT and ST fields were converted to MT in the summer of 2005. We quantified C and N stocks of three size fractions (53-250, 250-1000, and 1000-2000 $\mu \mathrm{m})$ of POM $(0-0.15 \mathrm{~m}$ depth). The POM-C 53-250 $\mu \mathrm{m}$ and $250-1000 \mu \mathrm{m}$ fractions decreased by $25 \%$ and $36 \%$ after six months under ST, whereas relatively little change occurred under NT, suggesting significant tillage effects over the period 2003-2004. Only small changes in POM content then occurred under MT on both fields. Changes in POM-N were similar to POM-C changes upon tillage conversions. This suggests that reduced tillage did not lead to soil C increase compared to ST but may help maintain the level of soil C for a typical California farming system. Short-term, field level variability of POM was primarily affected by tillage and was further influenced by clay content, bulk density, and scale of observation.

Copyright (C) 2009 Juhwan Lee et al. This is an open access article distributed under the Creative Commons Attribution License, which permits unrestricted use, distribution, and reproduction in any medium, provided the original work is properly cited.

\section{Introduction}

There is growing evidence that the amount of soil organic $\mathrm{C}$ and $\mathrm{N}$ storage tends to increase following the conversion from ST to reduced tillage, such as NT and MT $[1,2]$. Therefore, agricultural soils under reduced tillage practices may have the potential to mitigate greenhouse gas (GHG) emissions $[3,4]$. However, the effect of reduced tillage on soil $\mathrm{C}$ and $\mathrm{N}$ changes is still not conclusive, as the relationship between soil organic matter (SOM) and its controlling processes is highly variable across all spatial and temporal scales [4-6]. This is likely because a number of biotic and abiotic variables controlling the loss and sequestration of SOM frequently interact over space and time [7].

Many field studies have compared tillage systems using controlled experiments where treatments are randomly replicated at relatively small scales [8]. Patterns and related processes analyzed at these small-scale studies, however, are often difficult to be validated at larger scales due mostly to scale dependency [9]. Recently, on the other hand, the scientific community is recognizing the importance of con- ducting research at scales of agricultural management [10]. Unfortunately, it is often found to be physically impossible or economically undesirable to replicate large-scale field trials $[11,12]$, especially in farmer's fields. Therefore, large-scale variation itself is being embraced because it can be used to test and refine interactions among controlling factors (e.g., soil properties, microclimate, etc.) and agricultural management practices $[7,13]$. Understanding these interactions at a larger scale is of primary importance for a comprehensive evaluation of potential benefits and drawbacks of reduced tillage.

For unreplicated field studies, one needs to explore alternative statistical methods to compare large-scale systems that are characterized by high variation. A Before-After Control-Impact (BACI) approach can be used to detect treatment-induced changes in field-scale processes [14, 15]. To account for problems of spatial and temporal variation, the field should be paired with a similar field not exposed to the treatment of interest. It is not reasonable to expect that the two paired fields will have a similar degree of changes in processes. Thus, results from BACI are sometimes 
ambiguous because more than one interpretation is possible on paired observations [16]. However, if obvious differences in spatial and temporal patterns develop after dividing a field into a continuing treatment versus a contrasting treatment then one can reasonably postulate that they are caused by the treatments. More detailed discussions of BACI are presented elsewhere [14, 16-19].

At the field scale, it is difficult to detect short-term changes in SOM in response to management changes because of large background levels and high spatial variability of SOM $[20,21]$. Studies suggest that measures of POM can provide an indication of longer-term changes of SOM due to tillage effects $[22,23]$. The POM fraction can contribute up to $40 \%$ of the total SOM in near-surface horizons, primarily derived from root materials in various stages of decomposition [22, 24]. Cambardella and Elliott [22] showed that POM has a faster $\mathrm{C}$ turnover rate than whole soil organic $\mathrm{C}$ or mineral-associated $\mathrm{C}$. Within the POM fraction, the coarse $(250-2000 \mu \mathrm{m})$ POM fraction is the most sensitive to changes in residue input and decomposition rate by tillage [1]. The fine $(53-250 \mu \mathrm{m}) \mathrm{POM}$ is, on the other hand, relatively less sensitive to changes in management and is a more stabilized POM fraction [23].

The effects of reduced tillage on SOM and POM levels have been intensively investigated in the Great Plains and Corn Belt Regions [3, 25, 26]. In contrast, few such studies have been conducted in California [27]. Differences in the magnitude of tillage-induced changes in SOM between sites and regions are still poorly understood for Californian agroecosystems. In particular, no field-scale studies evaluating tillage effects on SOM changes have been performed in California. Therefore, we hypothesized that in a typical California farming system, the change in the rate of soil C cycling, induced by reduced tillage, leads to a predictable increase in soil $\mathrm{C}$ sequestration across the field. The objectives of this study were (i) to determine horizontal and temporal changes in POM contents under ST, NT, and MT practices in a Mediterranean agroecosystem and (ii) to determine effects of selected soil physical properties on POM contents across fields under different tillage systems.

\section{Materials and Methods}

2.1. Site Description and Sampling Scheme. In 2003, an experimental site was established on a 30-ha agricultural field ( $38^{\circ} 36^{\prime} \mathrm{N}, 121^{\circ} 50^{\prime} \mathrm{W}$ ) located in the Sacramento Valley of California. The site has been land planed for irrigation with a slope of about $1 \%$. Irrigation was primarily by furrow irrigation, but sprinkler irrigation was used for seed germination if necessary (Figure 1). The mean annual temperature and precipitation were $16.1^{\circ} \mathrm{C}$ and $564 \mathrm{~mm}$, respectively. Two major and one minor soil series occur on the site: Myers clay (fine, montmorillonitic, thermic Entic Chromoxerert), Hillgate loam (fine, montmorillonitic, thermic Typic Palexeralf), and San Ysidro loam (fine, montmorillonitic, thermic Typic Palexeralf) [28].

The site was managed under NT management in 2001 and 2002. Following sudangrass (Sorghum vulgare) in 2001

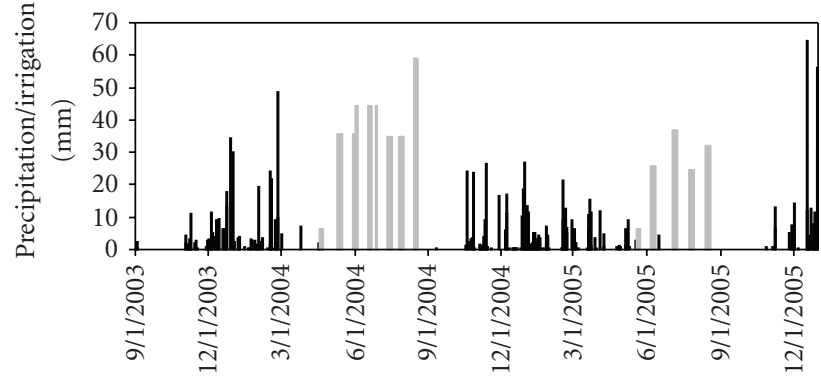

(a)

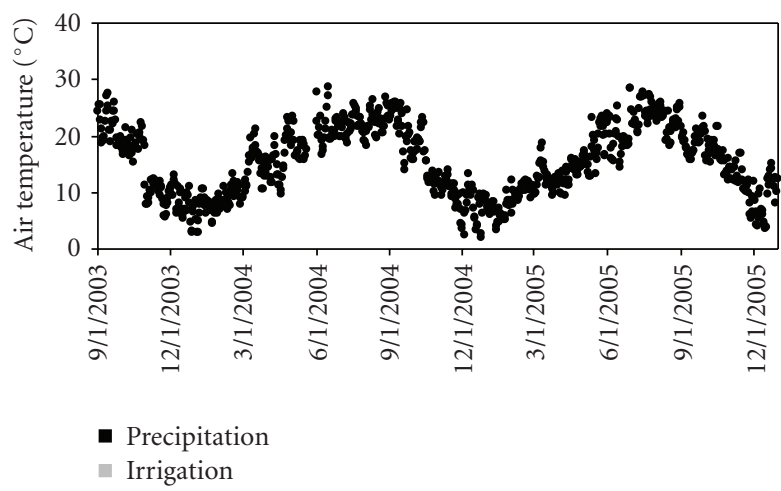

(b)

Figure 1: Precipitation, irrigation, and daily mean air temperature at the field site, September 2003-December 2005.

and maize (Zea mays) in 2002, the field was seeded to winter wheat (Triticum aestivum). After the harvest of the winter wheat in June 2003, the site was split into two fields in October 2003, with the north half of the site converted to ST management practices and the south half remaining under NT. The ST treatments consisted of one pass each of deep ripping to $45 \mathrm{~cm}$, stubble disking, disking to $15 \mathrm{~cm}$, grading, and listing the seed beds (in $0.75 \mathrm{~m}$ rows). The terminology used to describe these tillage systems in California is that presented by Mitchell et al. [29]. Both fields remained fallow until maize was planted on April 12 and 13, 2004. At planting, urea-ammonium nitrate (32-0-0 NPK) was band applied $(0.10 \mathrm{~m}$ depth $)$ at a rate of $55 \mathrm{~kg} \mathrm{Nha}^{-1}$. An additional $21 \mathrm{~kg} \mathrm{~N} \mathrm{ha}^{-1}$ was broadcast applied as 8-24$6 \mathrm{NPK}$. In addition, $168 \mathrm{~kg} \mathrm{Nha}^{-1}$ of $\mathrm{N}$-fertilizer was side dressed at 15-cm depth on May 24 and 25, 2004. Goats grazed the field of wheat and maize residue for 1-4 weeks after harvest and before tillage in 2003 and after harvest in 2004. The whole field was fenced off and divided into four identical areas. Goats spent a similar amount of time in each area. Grazing resulted in a decrease of $53 \pm 2 \%$ (mean \pm standard error) and $63 \pm 3 \%$ in the amount of aboveground residue C for wheat (2003) and maize (2004), respectively, (data not shown). The difference between the fields was on average $4 \%$ in 2003 and $1 \%$ in 2004. Manure returns of $\mathrm{C}$ were almost negligible (less than $3 \%$ of total $\mathrm{C}$ input from the crop). As goats were not observed to range widely during short time intervals, we assumed that grazing effects on $\mathrm{C}$ input levels were similar for the two fields, and homogeneous within each field. 


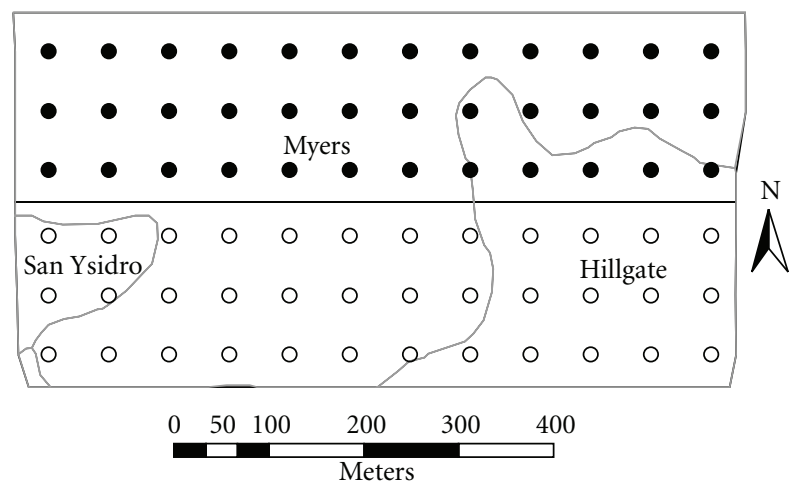

FIgUre 2: Layout of sampling points. The sampling points on the $64 \mathrm{~m}$ grid are indicated with solid circles for the north and open circles for the south field.

In May 2005, maize stubble was chopped in both fields, with three bed disc (to $15 \mathrm{~cm}$ ) passes on the north side of the field and two passes on the south. Both fields also had one mulcher pass and pre-emergent herbicide incorporated. Male sunflowers (Helianthus annuus.) were planted on May 16, 2005, and females were planted on May 23. Fertilizer (UAN-32) was applied at a rate of $90 \mathrm{~kg} \mathrm{~N} \mathrm{ha}^{-1}$ in a sidedress application on June 17-18.

2.2. Soil and Plant Sampling. Soil and plant samples were taken from the fields at 72 global position system referenced locations on $64 \mathrm{~m}$ regular grids (Figure 2). In August 2003, the $1 \mathrm{~m}$ soil profile $(0.05 \mathrm{~m}$ in diameter $)$ was sampled at each sampling location two months prior to tillage and split into $0-0.15,0.15-0.3,0.3-0.5,0.5-0.75$, and $0.75-1 \mathrm{~m}$ depth increments to analyze spatial variations in soil $\mathrm{C}$ and $\mathrm{N}$ and their controlling factors before the imposition of the ST treatments. Soil cores were taken to a depth of $0-0.15 \mathrm{~m}$ at the same locations in April and October 2004 (6 and 12 months under ST versus NT), and in June 2005 (one month after the conversion of both ST and NT to MT). Wheat shoot samples were collected in the fields at the same 72 locations in June 2003 at harvest to estimate residue C input in soil (see below).

2.3. Soil and Plant Analyses and Calculations. Field-moist soil samples were sieved to pass $<8 \mathrm{~mm}$, and subsamples were dried at $105^{\circ} \mathrm{C}$ overnight to determine gravimetric water content and bulk density (BD). The remaining sample was air-dried, mechanically crushed, and sieved to pass through a $2 \mathrm{~mm}$ mesh. Plant residues $(>2 \mathrm{~mm}$ ) were removed from the samples, and rock fragments were separated and weighed for BD and water content corrections. Soil particle size distribution was determined by the laser diffraction method using a Beckman-Coulter LS-230 with a $750 \mathrm{~nm}$ laser beam [30].

Soils were analyzed for $\mathrm{C}$ and $\mathrm{N}$ stocks of total SOM and POM (i.e., 53-250, 250-1000, and 1000-2000 $\mu \mathrm{m}$ size fractions). To separate POM and sand fractions, a 2-mmsieved, air-dried subsample ( $30 \mathrm{~g})$ was dispersed by shaking in $0.5 \%$ sodium hexametaphosphate solution $(100 \mathrm{~mL})$ for
18 hours [22]. The dispersed sample was passed through a series of three sieves $(1000,250$, and $53 \mu \mathrm{m})$, and all fractions were thoroughly rinsed and transferred to preweighed pans. All POM fractions were oven-dried overnight at $65^{\circ} \mathrm{C}$, weighed, ground and stored at room temperature.

Plant samples were oven-dried at $60^{\circ} \mathrm{C}$ for 48 hours, separated into residue and grain fractions, and then ground $(<0.5 \mathrm{~mm})$. The ground plant samples were further ground using a ball grinder for chemical analysis. Organic $\mathrm{C}$ and $\mathrm{N}$ content, and $\delta^{13} \mathrm{C}$ in the bulk soil, POM fractions, and plant samples were measured with a PDZ Europa ANCA CN analyzer connected to a PDZ Europa 20-20 Isotope Ratio Mass Spectrometer (SerCon, Cheshire, UK).

The stocks of soil organic $\mathrm{C}$ and $\mathrm{N}$ were expressed on an equivalent soil mass basis [31], using the following equations:

$$
\begin{aligned}
M_{\text {soil }}= & \mathrm{BD} \cdot \text { depth } \\
M_{\text {element }}= & \operatorname{conc} \cdot M_{\text {soil }} \cdot 1000 \\
& -\operatorname{conc} \cdot\left(M_{\text {soil }}-M_{\text {soil equiv }}\right) \cdot 1000,
\end{aligned}
$$

where $M_{\text {element }}$ is the equivalent $\mathrm{C}$ or $\mathrm{N}$ mass $\left(\mathrm{g} \mathrm{m}^{-2}\right)$, conc is concentration of organic $\mathrm{C}$ or $\mathrm{N}\left(\mathrm{g} \mathrm{kg}^{-1}\right.$ soil), $\mathrm{BD}$ is bulk density $\left(\mathrm{Mg} \mathrm{m}^{-3}\right)$, depth is the depth of horizon (m), the factor 1000 is a factor for unit conversions, $M_{\text {soil }}$ is soil mass to the depth of horizon $\left(\mathrm{Mg} \mathrm{m}^{-2}\right)$, and $M_{\text {soil equiv }}$ is equivalent soil mass $\left(\mathrm{Mg} \mathrm{m}^{-2}\right)$, which is the mass of the least dense sample among the soil samples at each sampling time.

To estimate the amount of new $\mathrm{C}$ input derived from fresh wheat residue into POM-C during the first eight months of the study (from August 2003 to April 2004), we used the $\delta^{13} \mathrm{C}$ values for POM fractions and wheat residues. A simple mixing model [32] was used to calculate soil POM$\mathrm{C}_{\text {new: }}$ :

$$
\begin{gathered}
P=\left(\frac{\delta_{\mathrm{t} 1}-\delta_{t 0}}{\delta_{\mathrm{w}}-\delta_{\mathrm{t} 0}}\right) \\
\text { soil } P O M-\mathrm{C}_{\mathrm{new}}=\mathrm{eq} \cdot \mathrm{conc}_{\mathrm{t} 1} \times P,
\end{gathered}
$$

where $\mathrm{P}$ is the proportion of $\mathrm{C}$ derived from wheat residues in the POM fractions between time 0 and $1, \delta_{\mathrm{t} 0}$ and $\delta_{\mathrm{t} 1}$ are the $\delta^{13} \mathrm{C}$ values of the POM fraction at time 0 (August 2003) and 1 (April 2004), $\delta_{\mathrm{w}}$ is the average $\delta^{13} \mathrm{C}$ value of wheat residue $(-27.7 \%)$, and eq $\cdot$ conc $_{\mathrm{t} 1}$ is the concentration of POM-C ( $\mathrm{g}$ $\mathrm{C} \mathrm{m}^{-2}$ ) calculated on an equivalent soil mass basis for time 1 .

2.4. Statistical Analysis. Variables were tested for nonnormality using the D'Agostino-Pearson omnibus test in SAS $[33,34]$. Outliers with an absolute value of more than 3 standard deviations from the mean were excluded from the descriptive statistics and geostatistical and multivariate regression analyses [35]. On average, there was less than one outlier for each variable for each sampling time.

By accounting for spatial correlation, image maps of POM fractions were produced at each sampling time in Surfer 8 (Golden Software, Golden, CO). Briefly, simple linear regression was first performed on the 64-m regular grid 
TABLE 1: Statistical summary of the surface horizon $(0-0.15 \mathrm{~m})$ characteristics in August 2003.

\begin{tabular}{|c|c|c|c|c|c|c|c|c|}
\hline Field & & Total C $\left(\mathrm{g} \mathrm{C} \mathrm{m}^{-2}\right)$ & Total $\mathrm{N}\left(\mathrm{g} \mathrm{N} \mathrm{m}^{-2}\right)$ & Sand $(\%)$ & Silt (\%) & Clay $(\%)$ & $\mathrm{BD}\left(\mathrm{Mg} \mathrm{m}^{-3}\right)$ & Water content $\left(\mathrm{m}^{3} \mathrm{~m}^{-3}\right)$ \\
\hline \multirow{4}{*}{ North } & Mean & 1287 & 115.6 & 27.3 & 54.3 & 18.6 & 1.40 & 0.10 \\
\hline & Minimum & 994 & 92.8 & 20.5 & 46.2 & 13.2 & 0.81 & 0.05 \\
\hline & Maximum & 1524 & 145.3 & 42.7 & 59.6 & 22.5 & 1.88 & 0.16 \\
\hline & $\mathrm{CV}(\%)^{\dagger}$ & 9 & 10 & 23 & 7 & 14 & 18 & 27 \\
\hline \multirow{4}{*}{ South } & Mean & 1100 & 105.8 & 37.0 & 48.2 & 14.8 & 1.47 & 0.08 \\
\hline & Minimum & 698 & 72.7 & 23.3 & 37.1 & 11.1 & 0.98 & 0.04 \\
\hline & Maximum & 1448 & 128.7 & 48.9 & 59.6 & 20.7 & 1.86 & 0.14 \\
\hline & CV (\%) & 17 & 13 & 20 & 12 & 16 & 15 & 33 \\
\hline
\end{tabular}

${ }^{\dagger} \mathrm{CV}$ : coefficient of variation.

with $\mathrm{x}$ and $\mathrm{y}$ coordinates as independent variables to identify if there were significant $(P<.05)$ spatial trends in POM fractions. When a significant trend with direction existed, trend values were calculated at all sampling points using the trend model and then subtracted from the measured values. Semivariogram models were defined to determine the spatial structure of the residuals from the trend, and the residuals were then block-kriged and added back to the trends using their respective semivariogram models in GS+ (Gamma Design Software, St. Planinwell, MI). The best model was selected based on visual fit, reduced sums of squares, and $r^{2}$ of the regression and through cross validation [36]. When there was no significant trend, semivariograms and estimation were made using the measured POM data. Due to a relatively small number $(N=36)$ of samples in each field, anisotropic semivariograms were not considered for each of the data sets [36]. For data sets showing a very weak spatial correlation, point kriging with a linear model was used for interpolation.

Repeated measurements over time were used to compare tillage-induced changes in POM-C and $-\mathrm{N}$ by the interaction of field (i.e., between the north and south fields) and sampling time (i.e., before versus after potential differences in tillage effects) using a mixed model in SAS [15, 34]. All the POM$\mathrm{C}$ and-N fractions were log-transformed for $\mathrm{BACI}$ analysis. Significant main effects of the factors "field" and "sampling time" may indicate the presence of inherent differences and temporal fluctuations across and within the fields that persisted throughout the study. We assumed that these effects of "field" and "sampling time" were not directly controlled by the treatment. Due to difficulty in establishing the control field, we excluded the period of both fields being under MT for the BACI analyses. All BACI model residuals by field or sampling time were checked for independence by visually inspecting histograms and empirical semivariograms, and correlation analysis. A $P$-value of .02 was used to avoid a type I error.

Standardized partial regression coefficients were used to assess the impact of soil texture, BD, and water content on POM. Regression coefficients were obtained by developing a mixed model for each response variable (after log transformation to meet normality) in $\mathrm{R}$ using the nlme package [37]. A final model was obtained by backward elimination, starting with a full model that included a full factorial of field, time, sand, clay and BD, minus all interactions of order equal to or greater than four. Location was the random effect. All effects and interactions with a $P$-value greater than .05 were removed, except when there was a significant interaction involving the effect. Random effects and residuals were checked for normality by visual inspection of quantile plots. Homogeneity of variance was checked by plotting residuals against predicted values. Spatial independence was checked by calculating the empirical semivariograms for residuals and random effects.

Due to the unreplicated nature of the tillage treatments, the inference about the effect of ST versus NT on POM was limited to the two paired fields used in this study. When necessary, descriptive statistics were used to compare results between the fields.

\section{Results and Discussion}

3.1. Field Level Variability of Soil Properties. The amount of additional $\mathrm{C}$ and $\mathrm{N}$ that can be sequestered in soil by implementing reduced tillage closely depends on both spatial and temporal variability of soil processes [7]. Thus, by including the spatial and temporal variability of soil $\mathrm{C}$ and $\mathrm{N}$ stocks as well as soil properties, a more realistic measure of additional $\mathrm{C}$ and $\mathrm{N}$ changes can be made at the field scale. There was considerable spatial variability among soil C and $\mathrm{N}$ and related physical soil properties across the two fields in August 2003 before the tillage conversion (Table 1). The soil heterogeneity of the fields is partially due to the spatial distribution of three soil series across the fields, but also within soil types variability was observed. In the surface zone $(0-0.15 \mathrm{~m})$, soil-water content was the most variable among the measured soil properties, with coefficient of variation $(\mathrm{CV})$ values of 27 and $33 \%$, followed by sand content $(\mathrm{CV}$ $=20$ and $23 \%$ ). Total $\mathrm{C}, \mathrm{N}$, clay content, and $\mathrm{BD}$ had less variability $(C V=9$ and $18 \%)$. Silt content $(C V=7$ and $12 \%$ ) was the least variable and contributed approximately $50 \%$ to the total particle mass. Total $\mathrm{C}$ and $\mathrm{N}$ contents were spatially $(P<.05)$ correlated with clay content and decreasing sand content. Total $\mathrm{C}$ and $\mathrm{N}$ contents were higher in the north field $\left(1287 \mathrm{~g} \mathrm{C} \mathrm{m}^{-2}\right.$ and $\left.115.6 \mathrm{~g} \mathrm{~N} \mathrm{~m}^{-2}\right)$ than the south field ( $1100 \mathrm{~g} \mathrm{C} \mathrm{m}^{-2}$ and $\left.105.8 \mathrm{~g} \mathrm{~N} \mathrm{~m}^{-2}\right)$. Within each of the fields, soil-profile $\mathrm{C}$ distribution was relatively uniform across the depth of tillage (e.g., $0.15-0.45 \mathrm{~m}$ in this study) (Figure 3). On average, the north and south fields contained approximately 1190 and $1000 \mathrm{~g} \mathrm{C} \mathrm{m}^{-2}$ in the upper $0.5-\mathrm{m}$ 


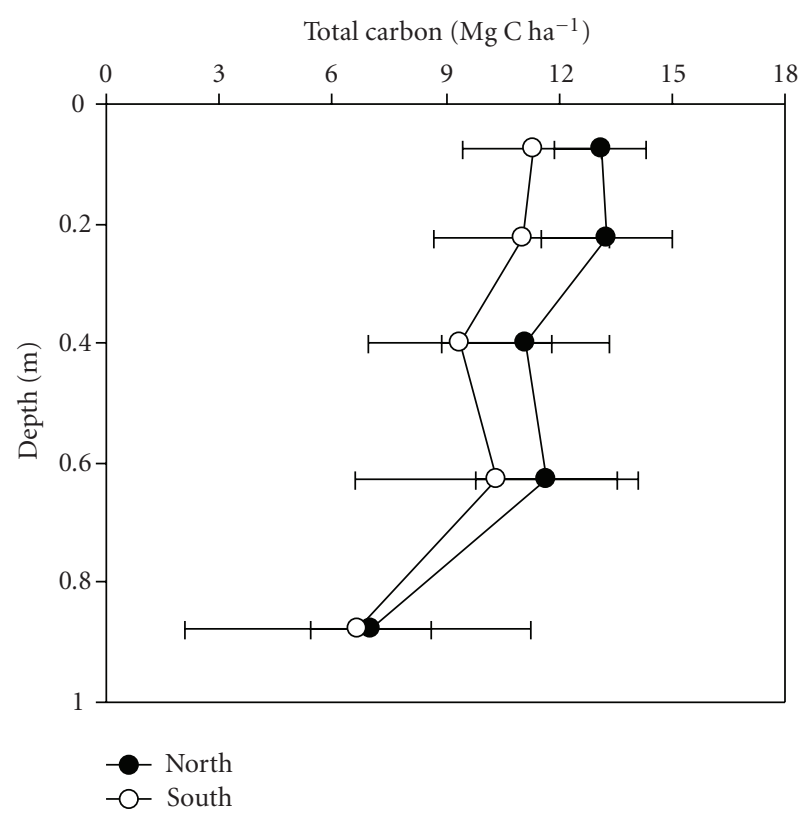

FIgURE 3: Total soil carbon content across depths prior to the tillage operations. Bars indicate the standard deviation of the mean.

depth, respectively. This is a common phenomenon when agricultural soils are subjected to frequent soil disturbance and mixing by intensive tillage. The north field had higher clay (19\% at the north field versus $15 \%$ at the south field) and silt content (54\% versus $48 \%$ ) and lower sand content $(27 \%$ versus $37 \%$ ) than the south field. Water content was higher in the north $\left(0.10 \mathrm{~m}^{3} \mathrm{~m}^{-3}\right)$ than the south field $\left(0.08 \mathrm{~m}^{3} \mathrm{~m}^{-3}\right)$. Both fields had a BD of approximately $1.4-1.5 \mathrm{Mg} \mathrm{m}^{-3}$. The measured soil variables were normally distributed at the field scale, except for water content in the south field (data not shown).

The means for each of the physical properties differed by 9-26\% between the fields, except for BD (Table 1). Despite the mean differences in the soil properties, the majority of ranges overlapped in both fields, suggesting that the spatial and temporal variability of factors influencing soil organic $\mathrm{C}$ and $\mathrm{N}$ dynamics may not be different between the fields. Specifically, $61-94 \%$ of the measured soil property range for the north field and 53-94\% for the south field were similar to each other.

\subsection{Short-Term Changes in Soil Bulk Density and Water under} Tillage Systems. Two months after the tillage conversion in 2003, the mean $\mathrm{BD}$ values at the $0.15 \mathrm{~m}$ depth were higher in the south field under NT $\left(1.24 \mathrm{Mg} \mathrm{m}^{-3}\right)$ than in the north field under ST $\left(1.00 \mathrm{Mg} \mathrm{m}^{-3}\right)$ (Figure 4). The BD then increased in ST to almost the same value as in the NT. These results are in accordance with the often observed large temporal changes of $\mathrm{BD}$ that could result in insignificant tillage effects on BD [31]. Soil BD is often more influenced by soil properties, climatic conditions and their seasonal variations rather than tillage practices $[25,38-$ 41]. Overall, the response of surface horizon BD to tillage

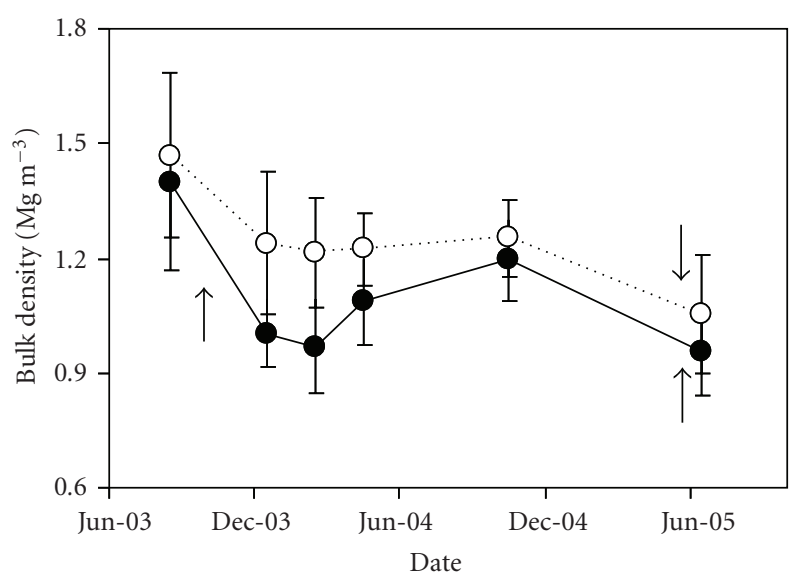

(a)

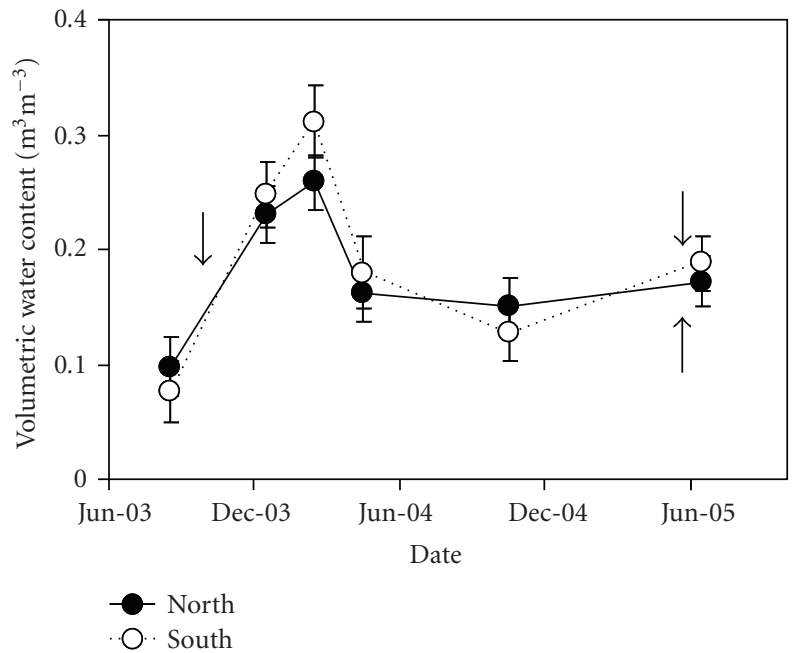

(b)

FIGURE 4: Seasonal changes in bulk density and volumetric water content. Arrows indicate the time of the tillage operations. The north field was converted from no-till to standard tillage in August 2003, while the south field remained under no-till. Both fields were then converted to minimum tillage in May 2005. Bars indicate the standard deviation of the mean.

treatments greatly depends on time of determination and tillage intensity [42].

Soil-water conditions are closely associated with changes in soil biochemical properties (e.g., mineral N) over space and time [43,44]. Lee et al. [43] showed that soil-water conditions, which were regulated by tillage and irrigation, could affect the bioavailability and type of soil $\mathrm{C}$ and $\mathrm{N}$ sources for microbial activity in irrigated agricultural systems of California, hence continuously altering SOM mineralization $[45,46]$. Soil-water content prior to the tillage conversion was greater in the north field than the south field (Figure 4). Following tillage in the ST field, soil-water content increased for both fields during the rainy season (November 2003 March 2004) (Figure 4). Over the period of this study, there was no effect of tillage on soil water content. Consequently, the water content differences between the fields under ST and NT were not large enough and 


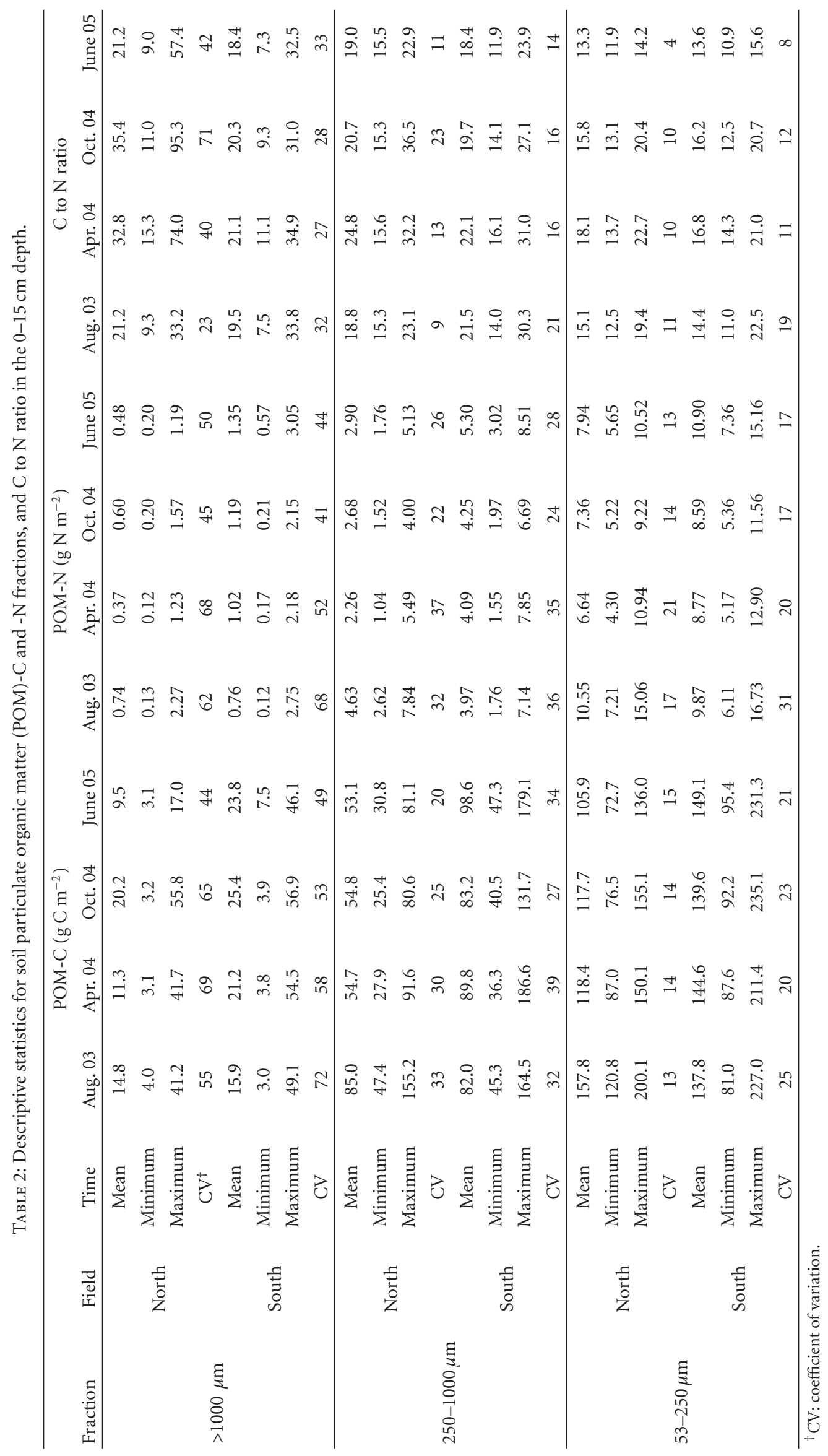




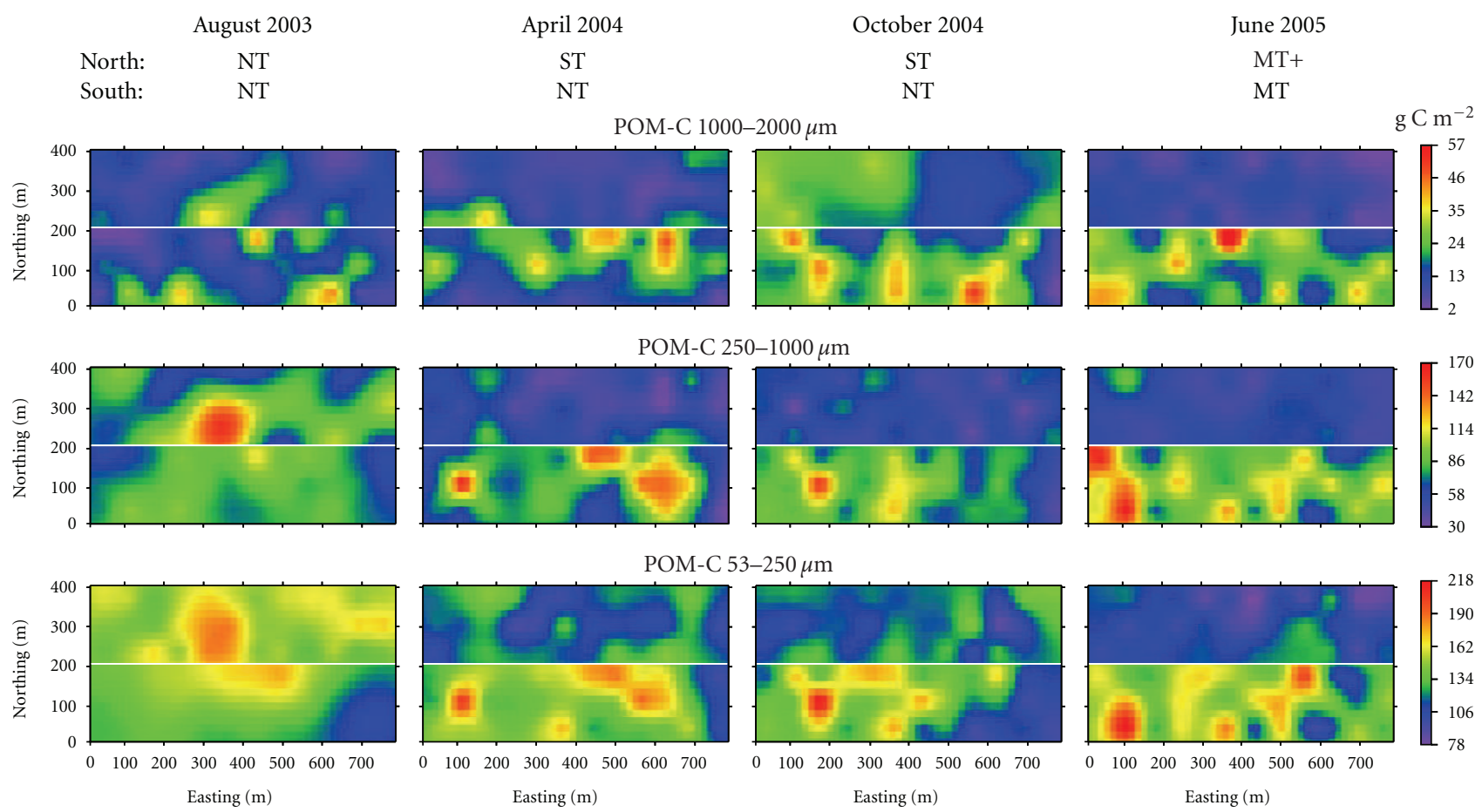

FIGURE 5: Distribution of soil particulate organic matter C (POM-C) for standard tillage (ST), no-till (NT), and minimum tillage (MT) in the $0-0.15 \mathrm{~m}$ depth from August 2003 to June 2005. MT+ indicates one more bed disc (to $0.15 \mathrm{~m}$ ) pass on the north field.

consistent in direction to suggest that conversion to reduced tillage can lead to short-term gains in water conservation as has been observed in the Great Plains and the Midwest $[47,48]$.

3.3. Spatial Variation in Particulate Organic Matter. Prior to the tillage conversion, soil POM exhibited large spatial variability within and across the fields (Table 2 and Figure 5) and total POM (53-2000 $\mu \mathrm{m})$ accounted for approximately $21 \%$ and $14 \%$ of total C and $\mathrm{N}$ stocks, respectively, in the top $15 \mathrm{~cm}$ of the soils (Tables 1 and 2). The combined $\mathrm{C}$ and $\mathrm{N}$ stocks in the POM 53-250 $\mu \mathrm{m}$ and $250-1000 \mu \mathrm{m}$ fractions accounted for $94 \%$ and $83 \%$ of total POM-C and $-\mathrm{N}$ across the fields, respectively. Despite high spatial variability of $\mathrm{POM}, \mathrm{C}$ and $\mathrm{N}$ stocks of all size classes of POM decreased across the north field following the tillage conversion, while there was only little change in the south field with time under continuous NT (Table 2 and Figure 5). Others have also reported that POM levels generally decreased with increasing tillage intensity $[49,50]$. This suggests that the spatial distribution of POM stocks in the fields was in part affected by tillage at the field scale. With a subsequent conversion to MT in both fields, little or no change in spatial distribution of POM-C stocks occurred. Image maps of the POM-N fractions exhibited a similar spatial pattern with respect to the tillage treatments (data not shown). Regardless of the tillage treatments, the coefficient of variation of POM$\mathrm{C}$ and $-\mathrm{N}$ increased with increasing size fraction because plant residue input was dominantly incorporated into coarse POM compared to fine POM [51].
The POM C/N ratios were on average slightly higher in the north field than those in the south field, mostly due to different amount of recently incorporated wheat residues (Table 2). In 2003, the $\mathrm{C} / \mathrm{N}$ ratio of the wheat residue was $86 \pm 7$ (mean \pm standard error) (data not shown). Across the fields and sampling times, the $\mathrm{C} / \mathrm{N}$ ratios ranged $13-$ $18,18-25$, and $18-35$ for the 53-250, 250-1000, and 1000$2000 \mu \mathrm{m}$ fractions, respectively. This tendency of increasing $\mathrm{POM} \mathrm{C} / \mathrm{N}$ ratios with size suggests that fine POM was more decomposed than coarse POM $[24,52,53]$. There was no measureable enrichment of $\mathrm{C}$ relative to $\mathrm{N}$ in POM under NT when compared to ST, which is consistent with the results of Cambardella and Elliott [22].

3.4. Temporal Variation in Particulate Organic Matter. After the tillage conversion in 2003, C and N stocks of all the POM fractions were significantly higher in NT than ST at the two subsequent sampling times (Tables 2, 3 and 4). We found a consistent interactive effect of field by sampling time on both POM-C and -N. Contrast analyses suggest that the differences $(P<.01)$ between tillage systems were significant for all POM fractions in April and October 2004 and the overall 12 months period after the tillage conversion. The major differences in POM fractions between tillage practices appeared between August 2003 and April 2004. In the north field, the average $\mathrm{C}$ and $\mathrm{N}$ stocks of the POM 53-250, 250-1000, and 1000-2000 $\mu \mathrm{m}$ fractions decreased by approximately 25,36 , and $23 \%$ for $\mathrm{C}$ and 37,51 , and $50 \%$ for $\mathrm{N}$ (Table 2). In contrast, both $\mathrm{C}(\approx 5 \%)$ and $\mathrm{N}$ stocks $(\approx 10 \%)$ of the POM $53-250 \mu \mathrm{m}$ and $250-1000 \mu \mathrm{m}$ fractions 
TABLE 3: Effect of standard tillage and no-till on particulate organic matter (POM)-C (BACI ${ }^{\dagger}$ analysis). All the POM-C fractions were log transformed.

\begin{tabular}{|c|c|c|c|c|c|c|}
\hline Fraction & Source & DF & Sum of squares & Mean square & $F$ value & $\operatorname{Pr}>F$ \\
\hline \multirow[t]{9}{*}{$>1000 \mu \mathrm{m}$} & Field & 1 & 1.042 & 1.042 & 12.94 & 0.001 \\
\hline & Time & 2 & 1.274 & 0.637 & 8.80 & 0.000 \\
\hline & Field $\times$ time & 2 & 0.678 & 0.339 & 4.69 & 0.011 \\
\hline & Location (field) & 70 & 5.639 & 0.081 & 1.11 & 0.294 \\
\hline & Residual & 140 & 10.135 & 0.072 & & \\
\hline & Contrast $\neq$ & & & & & \\
\hline & $T_{0}-T_{1}$ & 1 & & & 9.30 & 0.003 \\
\hline & $T_{0}-T_{2}$ & 1 & & & 1.67 & 0.199 \\
\hline & Overall means & 1 & & & 6.28 & 0.013 \\
\hline \multirow[t]{9}{*}{$250-1000 \mu \mathrm{m}$} & Field & 1 & 0.832 & 0.832 & 37.86 & $<0.0001$ \\
\hline & Time & 2 & 0.351 & 0.175 & 10.32 & $<0.0001$ \\
\hline & Field $\times$ time & 2 & 0.584 & 0.292 & 17.19 & $<0.0001$ \\
\hline & Location (field) & 70 & 1.539 & 0.022 & 1.29 & 0.100 \\
\hline & Residual & 140 & 2.379 & 0.017 & & \\
\hline & Contrast & & & & & \\
\hline & $T_{0}-T_{1}$ & 1 & & & 27.71 & $<0.0001$ \\
\hline & $T_{0}-T_{2}$ & 1 & & & 23.70 & $<0.0001$ \\
\hline & Overall means & 1 & & & 34.22 & $<0.0001$ \\
\hline \multirow[t]{9}{*}{$53-250 \mu \mathrm{m}$} & Field & 1 & 0.048 & 0.048 & 4.03 & 0.0487 \\
\hline & Time & 2 & 0.145 & 0.073 & 15.97 & $<0.0001$ \\
\hline & Field $\times$ time & 2 & 0.260 & 0.130 & 28.63 & $<0.0001$ \\
\hline & Location (field) & 70 & 0.831 & 0.012 & 2.61 & $<0.0001$ \\
\hline & Residual & 140 & 0.636 & 0.005 & & \\
\hline & Contrast & & & & & \\
\hline & $T_{0}-T_{1}$ & 1 & & & 48.79 & $<0.0001$ \\
\hline & $T_{0}-T_{2}$ & 1 & & & 36.15 & $<0.0001$ \\
\hline & Overall means & 1 & & & 56.31 & $<0.0001$ \\
\hline
\end{tabular}

${ }^{\dagger}$ BACI: Before-After and Control-Impact model.

${ }^{\ddagger}$ Difference in the interaction of field and time between August $2003\left(T_{0}\right)$, April $\left(T_{1}\right)$, and October $2004\left(T_{2}\right)$.

slightly increased in the south field, although the magnitude of change was significantly lower than for the north field under ST. Therefore, the contrasting effects of ST and NT on the $250-1000 \mu \mathrm{m}$ fractions were more evident than in the 53-250 $\mu \mathrm{m}$ fractions. The differences in POM persisted without much change thereafter, confirming preferential loss of POM at the time of intensive tillage management $[50,54]$. Overall, the temporal differences in POM-C between the fields induced by tillage were on average 7.8, 34.7, and $44.1 \mathrm{~g} \mathrm{~m}^{-2}$ for the 1000-2000, 250-1000, and 53-250 $\mu \mathrm{m}$ fractions. The differences in POM-N were 0.66, 2.35, and $2.36 \mathrm{~g} \mathrm{~m}^{-2}$ for the $1000-2000,250-1000$, and $53-250 \mu \mathrm{m}$ fractions. In addition, significant field or time effects indicate that the tillage effects are scale-dependent (Table 3 ).

The results show that the mean differences over time in the amount of each POM fraction were significantly lower in the north than in the south field, due to the level of tillage intensity and time since tillage. Coarse POM was more sensitive to tillage than fine POM, but the largest $C$ and $\mathrm{N}$ amounts were lost in the fine POM fraction as soon as tillage operations started. This suggests that fine POM is an important pool of soil C and $\mathrm{N}$ sensitive to soil disturbance.
No-till and MT appeared to maintain the level of soil POM relative to the level under ST, suggesting a capacity of reduced tillage in relative to ST to delay the loss of labile organic fractions under the Mediterranean climate conditions. We also found no major short-term ( $<3$ years) declines in $\mathrm{C}$ and $\mathrm{N}$ of the non-POM fraction (equivalent to mineralassociated SOM $<53 \mu \mathrm{m}$ ) in the north field when compared with the south field (Tables 2 and 4), leading to a greater proportion of non-POM in bulk SOM under ST than NT $[49,50,53]$.

3.5. New C Input to Soil in Standard and No-Tillage. Similar to POM-C, the concentration of new $\mathrm{C}$ input derived from wheat residue into each POM fraction had substantial spatial variability across the fields, with a range of CVs from 53 to $79 \%$ (Table 5). There were minor differences in the concentration of new POM-C derived from wheat residue between the fields, at least in the short term However, differences in $\delta^{13} \mathrm{C}$ in all the POM fractions over time (Figure 6) and the proportion of wheat-derived C/POM-C clearly showed faster turnover of new POM-C after seven months under ST than under NT. Even though more wheat 
TABLE 4: Effect of standard tillage and no-till on particulate organic matter (POM)-N (BACI ${ }^{\dagger}$ analysis). All the POM-N fractions were log transformed.

\begin{tabular}{|c|c|c|c|c|c|c|}
\hline Fraction & Source & $\mathrm{DF}$ & Sum of squares & Mean square & $F$ value & $\operatorname{Pr}>F$ \\
\hline \multirow[t]{9}{*}{$>1000 \mu \mathrm{m}$} & Field & 1 & 3.978 & 3.978 & 39.33 & $<0.0001$ \\
\hline & Time & 2 & 1.284 & 0.642 & 12.56 & $<0.0001$ \\
\hline & Field $\times$ time & 2 & 1.510 & 0.755 & 14.77 & $<0.0001$ \\
\hline & Location (field) & 70 & 7.087 & 0.101 & 1.98 & 0.000 \\
\hline & Residual & 140 & 7.106 & 0.051 & & \\
\hline & Contrast $^{\ddagger}$ & & & & & \\
\hline & $T_{0}-T_{1}$ & 1 & & & 29.17 & $<0.0001$ \\
\hline & $T_{0}-T_{2}$ & 1 & & & 11.08 & 0.001 \\
\hline & Overall means & 1 & & & 25.41 & $<0.0001$ \\
\hline \multirow[t]{9}{*}{$250-1000 \mu \mathrm{m}$} & Field & 1 & 0.920 & 0.920 & 40.65 & $<0.0001$ \\
\hline & Time & 2 & 0.834 & 0.417 & 25.22 & $<0.0001$ \\
\hline & Field $\times$ time & 2 & 1.144 & 0.572 & 34.61 & $<0.0001$ \\
\hline & Location (field) & 70 & 1.584 & 0.023 & 1.37 & 0.060 \\
\hline & Residual & 140 & 2.314 & 0.017 & & \\
\hline & Contrast & & & & & \\
\hline & $T_{0}-T_{1}$ & 1 & & & 59.75 & $<0.0001$ \\
\hline & $T_{0}-T_{2}$ & 1 & & & 42.63 & $<0.0001$ \\
\hline & Overall means & 1 & & & 67.77 & $<0.0001$ \\
\hline \multirow[t]{9}{*}{$53-250 \mu \mathrm{m}$} & Field & 1 & 0.115 & 0.115 & 9.43 & 0.003 \\
\hline & Time & 2 & 0.604 & 0.302 & 47.87 & $<0.0001$ \\
\hline & Field $\times$ time & 2 & 0.245 & 0.123 & 19.44 & $<0.0001$ \\
\hline & Location (field) & 70 & 0.854 & 0.012 & 1.93 & 0.0005 \\
\hline & Residual & 140 & 0.882 & 0.006 & & \\
\hline & Contrast & & & & & \\
\hline & $T_{0}-T_{1}$ & 1 & & & 38.16 & $<0.0001$ \\
\hline & $T_{0}-T_{2}$ & 1 & & & 14.64 & 0.000 \\
\hline & Overall means & 1 & & & 33.35 & $<0.0001$ \\
\hline
\end{tabular}

${ }^{\dagger}$ BACI: Before-After and Control-Impact model.

${ }^{\ddagger}$ Difference in the interaction of field and time between August $2003\left(T_{0}\right)$, April $\left(T_{1}\right)$, and October $2004\left(T_{2}\right)$.

TABle 5: Wheat-derived C and proportion of wheat-derived C/total fraction C in POM fractions under standard tillage and no-till in the first eight months of study.

\begin{tabular}{|c|c|c|c|c|c|c|}
\hline \multirow[b]{2}{*}{ Fraction } & \multicolumn{3}{|c|}{ Standard tillage } & \multicolumn{3}{|c|}{ No-till } \\
\hline & $>1000 \mu \mathrm{m}$ & $250-1000 \mu \mathrm{m}$ & $53-250 \mu \mathrm{m}$ & $>1000 \mu \mathrm{m}$ & $250-1000 \mu \mathrm{m}$ & $53-250 \mu \mathrm{m}$ \\
\hline \multicolumn{7}{|c|}{ Soil POM-C $\mathrm{C}_{\text {nw }}\left(\mathrm{g} \mathrm{C} \mathrm{m}^{-2}\right)$} \\
\hline Mean & 3.3 & 8.0 & 14.0 & 2.6 & 11.3 & 10.1 \\
\hline Maximum & 8.5 & 27.6 & 28.8 & 7.0 & 29.4 & 28.8 \\
\hline Minimum & 0.1 & 0.5 & 0.3 & 0.2 & 0.3 & 0.2 \\
\hline $\mathrm{CV}^{\dagger}$ & 65 & 73 & 53 & 79 & 60 & 75 \\
\hline Skewness $^{\ddagger}$ & 0.40 & 1.43 & 0.22 & 0.97 & 0.67 & 0.95 \\
\hline \multicolumn{7}{|c|}{ Soil POM-C ${ }_{\text {new }} /$ POM-C (\%) } \\
\hline Mean & 32.9 & 15.2 & 12.4 & 17.5 & 14.9 & 7.3 \\
\hline Maximum & 66.6 & 32.2 & 23.6 & 49.2 & 33.1 & 19.2 \\
\hline Minimum & 1.7 & 1.9 & 0.2 & 0.5 & 0.6 & 0.2 \\
\hline $\mathrm{CV}$ & 56 & 60 & 52 & 80 & 52 & 71 \\
\hline Skewness & -0.10 & 0.40 & -0.11 & 0.84 & 0.27 & 0.65 \\
\hline
\end{tabular}

${ }^{\dagger} \mathrm{CV}$ : coefficient of variation (\%).

${ }^{\ddagger}$ Skewness indicates the degree of asymmetry of a distribution. 


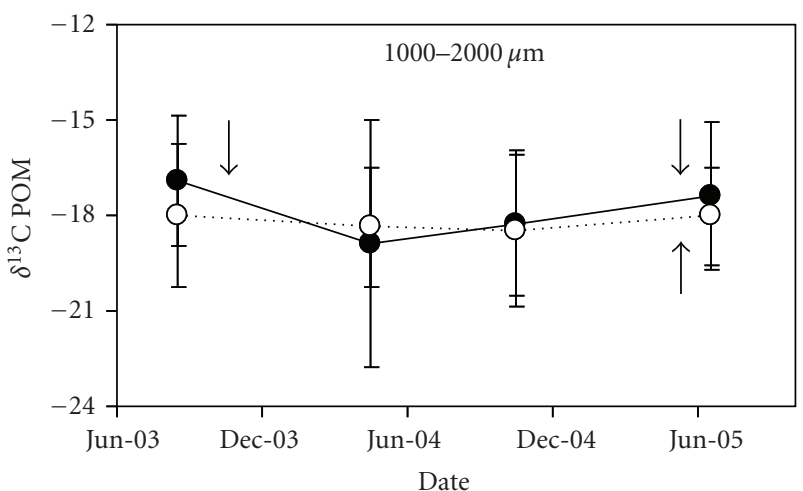

(a)

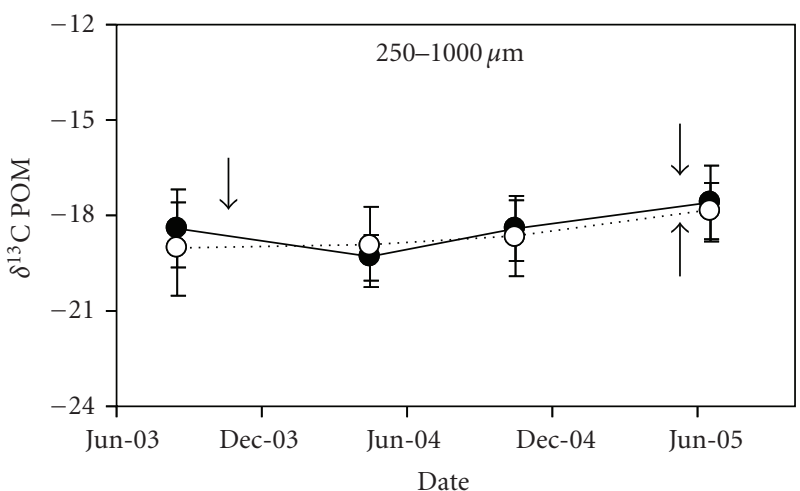

(b)

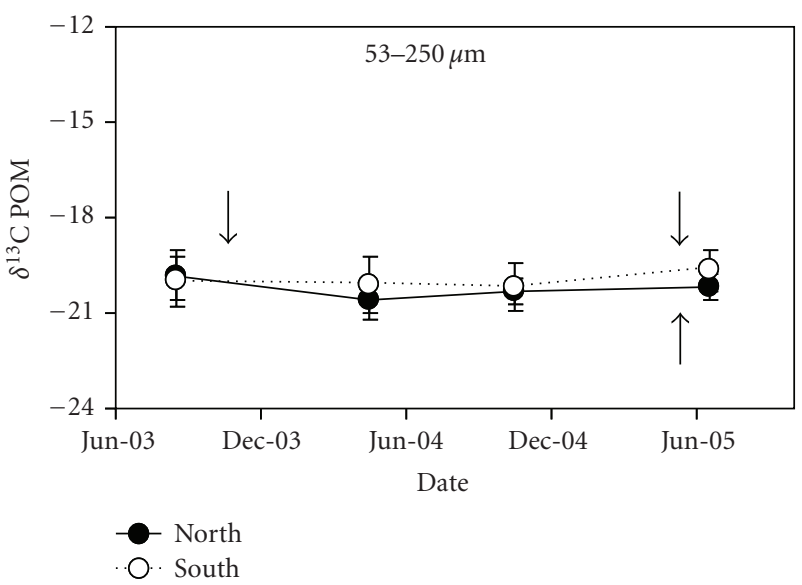

(c)

Figure 6: Short-term effect of tillage on $\delta^{13} \mathrm{C}$ particulate organic matter (POM). Arrows indicate the time of tillage operations. The north field was converted from no-till to standard tillage in August 2003, while the south field remained under no-till. Both fields were then converted to minimum tillage in May 2005. Bars indicate the standard deviation of the mean.

residue $\mathrm{C}$ was probably incorporated in the north field at the time of ST, our results indicate that simultaneously less residue-derived $\mathrm{C}$ accumulated as POM under ST than under NT. In contrast, NT had relatively high fine POM contents, primarily due to the lack of soil disturbance and increased residue cover [5].

Mean differences in new C input between ST and NT accounted for only $0-8.5 \%$ of the tillage-induced differences in POM-C (Tables 2 and 5). Therefore, the decomposition of old POM-C by tillage primarily led to total POM changes. Independent of the tillage treatments, the relative proportion of new $\mathrm{C}$ incorporated into each POM fraction decreased in the following order: $1000-2000 \mu \mathrm{m}>250$ $1000 \mu \mathrm{m}>53-250 \mu \mathrm{m}$. Therefore, NT also reduced the decomposition rate of pre-existing labile $\mathrm{C}$ and $\mathrm{N}$ in smaller POM fractions.

\subsection{Field Level Soil Controls on Particulate Organic Matter}

3.6.1. Soil Texture. Sand was a significant predictor of the coarse POM fractions, whereas clay was considered significant for controlling the fine POM fraction (Table 6).
Overall, sand content was positively related to the 1000$2000 \mu \mathrm{m}$ POM fraction (Table 7). We speculate that this is because soils with high sand content could store more crop residues as coarse POM than soils with low sand content. Clay may play a role in sequestering partly decomposed POM through physical and chemical protection of soil C and $\mathrm{N}[1$, $49,55]$, probably causing different responses of the fine POM fraction to varying tillage intensity and texture. However, the fine POM fraction in the soil surface significantly decreased with clay content across the fields (Table 7$)$. This could be explained by relatively low clay contents $(<20 \%)$ of the fields that have a tendency of fast degradation of POM after tillage is introduced.

For the coarse POM-C fractions, studies suggest that the degree of POM dependency on soil texture seems to be regulated by the level to which soil texture varies spatially between the fields with ST, NT, and MT [25, 56]. In addition, the relationships of sand and clay contents with other biotic and abiotic factors were largely affected by time and tillage [43]. As a result, this would significantly confound the dynamics of coarse POM. Our results are consistent with Wander et al. [40], showing that 
TABle 6: Significance of effects of soil physical properties on particulate organic matter (POM) $\mathrm{C}$ and $\mathrm{N}$ fractions, accounting for effects of field and time. All POM fraction values were logtransformed.

\begin{tabular}{|c|c|c|c|}
\hline Effect & $\begin{array}{c}>1000 \mu \mathrm{m} \\
\mathrm{POM}\end{array}$ & $\begin{array}{c}250-1000 \mu \mathrm{m} \\
\text { POM }\end{array}$ & $\begin{array}{c}53-250 \mu \mathrm{m} \\
\text { POM }\end{array}$ \\
\hline & \multicolumn{3}{|c|}{ POM-C } \\
\hline & \multicolumn{3}{|c|}{$P$-value } \\
\hline Field & 0.0001 & .0001 & 0.0001 \\
\hline Time & 0.0001 & .0001 & 0.0001 \\
\hline Sand & 0.0416 & .5101 & 0.0801 \\
\hline Clay & 0.1504 & .3504 & 0.0010 \\
\hline Bulk density & 0.0010 & .0001 & 0.0001 \\
\hline Field $\times$ time & 0.0001 & .0001 & 0.0001 \\
\hline Time $\times$ clay & 0.0043 & .0155 & 0.7712 \\
\hline Time $\times$ bulk density & 0.0196 & .0016 & 0.0399 \\
\hline Std. Dev. location & $\mathrm{NA}^{\dagger}$ & .0969 & 0.0935 \\
\hline \multirow[t]{3}{*}{ Std. Dev. residual } & 0.5762 & .2717 & 0.1499 \\
\hline & \multicolumn{3}{|c|}{ POM-N } \\
\hline & \multicolumn{3}{|c|}{$P$-value } \\
\hline Field & 0.0001 & .0001 & 0.0001 \\
\hline Time & 0.0001 & .0001 & 0.0001 \\
\hline Sand & 0.0001 & .015 & 0.8818 \\
\hline Clay & 0.1786 & .0912 & 0.0004 \\
\hline Bulk density & 0.1767 & .0011 & 0.0001 \\
\hline Field $\times$ time & 0.0001 & .0001 & 0.0001 \\
\hline Field $\times$ clay & $-^{\ddagger}$ & - & 0.2774 \\
\hline Time $\times$ clay & - & - & 0.7443 \\
\hline Field $\times$ time $\times$ clay & - & - & 0.0017 \\
\hline Std. Dev. location & 0.1858 & .0932 & 0.0814 \\
\hline Std. Dev. residual & 0.5061 & .2749 & 0.1631 \\
\hline
\end{tabular}

${ }^{\dagger} \mathrm{NA}$ : not applicable. The likelihood ratio test indicated that the random effect for location was not necessary and thus it was removed from the model according to Pinheiro and Bates (2000).

${ }^{\ddagger}$ The effect was removed from the model because it was not significant at the level of $2 \%$.

the relationship between soil texture and POM changed inconsistently over time. However, it was not evident what led to this shift in their relationship. In contrast, the relationship between the 53-250 $\mu \mathrm{m}$ POM-C fraction and clay appeared to be temporally consistent at the field scale. Therefore, the effect of clay on the dynamics of fine POM would be predominantly confounded by tillage and presumably independent of spatiotemporal variability in the other factors. Similarly, the effect of sand was positive or zero for the $250-2000 \mu \mathrm{m}$ POM-N fractions and the effect of clay was consistently negative for the $53-250 \mu \mathrm{m}$ POM-N fraction.

3.6.2. Soil Bulk Density. The BD was a significant predictor for all POM fractions except for the POM-N $>1000 \mu \mathrm{m}$
(Table 6). Regardless of the tillage treatments, the $\mathrm{BD}$ had a consistently negative effect on POM-C in all fractions at the field scale. Although the effect of BD on POM was greater but more variable than the effects of sand and clay in the majority of the cases, no significant differences were evident (Table 7). Tillage-induced changes in BD could be in part related to POM dynamics. For example, da Silva et al. [39] and Wander et al. [40] showed that there was a trend for decreasing bulk SOM with increasing $\mathrm{BD}$ under cultivation. Ball et al. [57] showed that maximum $\mathrm{BD}$ was negatively related to water content, total porosity, and clay content. We speculate that the rate of residue decomposition and new POM formation would be limited under lower soil water availability due to a high $\mathrm{BD}$, leading to decreased POM stocks. However, we were not able to find the evidence to support this speculation. The effects of $\mathrm{BD}$ on the POM-N fractions were similar to those of the POM-C, but slopes tended to be more constant over time.

3.6.3. Soil Water. The effect of soil water on POM was assessed by adding this factor to the reduced models obtained by backward elimination. Soil water was not significant for any of the response variables. This may be because water content is a too dynamic variable in comparison to POM. Although SOM mineralization can be greatly enhanced with increasing water content $[45,46]$, the spatial variation in soil conditions (e.g., soil texture) is likely responsible for variable and complex changes in soil chemical and biological properties [44]. Spatial patterns of such soil properties interacting with water were likely highly confounded by tillage.

\section{Conclusion}

Field level changes in soil POM was confounded by large spatial variability within and across the ST, NT, and MT fields, due in part to the influence of the natural field heterogeneity. Nevertheless, ST significantly accelerated changes in soil surface POM-C and - $\mathrm{N}$ in the initial period of the tillage conversion, but little seasonal changes occurred thereafter. Although coarse POM was more sensitive to tillage than fine POM, tillage-induced differences between the fields were greater for fine POM than for coarse POM. Accordingly, the relative contribution of total POM-C and $-\mathrm{N}$ to total SOM decreased in ST compared to NT. This suggests that fine POM is an important component of soil $\mathrm{C}$ and $\mathrm{N}$ cycling, at least in the short term. The faster turnover of new C in coarse POM under ST than NT indicates that reduced intensity tillage can improve SOM status by stabilizing pre-existing labile $\mathrm{C}$ and $\mathrm{N}$ sources in coarse POM.

The short-term $(<3$ years $)$ changes in POM-C, $-\mathrm{N}$, and new $C$ input affected by tillage were small relative to the spatiotemporal variability of non-POM or bulk SOM within each field. We found that the POM-C and $-\mathrm{N}$ themselves co-varied in space as a function of tillage at the field scale. Sand was a significant predictor of the short-term 
TABLE 7: Standardized partial regression coefficients relating soil physical properties to particulate organic matter (POM)-C and -N fractions. Numbers in the columns labeled $98 \% \mathrm{CI}$ are the half-width of the confidence intervals.

\begin{tabular}{|c|c|c|c|c|c|c|c|}
\hline Fraction & Time & Sand & $98 \% \mathrm{CI}$ & Clay & $98 \% \mathrm{CI}$ & Bulk density & $98 \% \mathrm{CI}$ \\
\hline \multicolumn{8}{|c|}{ POM-C } \\
\hline \multirow[t]{5}{*}{$>1000 \mu \mathrm{m}$} & August 03 & & & 0.03 & 0.339 & -0.10 & 0.221 \\
\hline & April 04 & & & -0.23 & 0.355 & -0.48 & 0.504 \\
\hline & October 04 & & & 0.37 & 0.343 & -0.53 & 0.497 \\
\hline & June 05 & & & 0.13 & 0.354 & -0.69 & 0.473 \\
\hline & All & 0.27 & 0.237 & & & & \\
\hline \multirow[t]{5}{*}{$250-1000 \mu \mathrm{m}$} & August 03 & & & -0.24 & 0.321 & -0.19 & 0.196 \\
\hline & April 04 & & & -0.45 & 0.334 & -0.87 & 0.447 \\
\hline & October 04 & & & 0.08 & 0.324 & -0.36 & 0.441 \\
\hline & June 05 & & & -0.16 & 0.334 & -0.76 & 0.419 \\
\hline & All & -0.01 & 0.247 & & & & \\
\hline \multirow[t]{5}{*}{$53-250 \mu \mathrm{m}$} & August 03 & & & -0.48 & 0.351 & -0.24 & 0.188 \\
\hline & April 04 & & & -0.62 & 0.362 & -0.66 & 0.431 \\
\hline & October 04 & & & -0.39 & 0.353 & -0.20 & 0.425 \\
\hline & June 05 & & & -0.55 & 0.362 & -0.64 & 0.402 \\
\hline & All & -0.47 & 0.297 & & & & \\
\hline \multicolumn{8}{|c|}{ POM-N } \\
\hline$>1000 \mu \mathrm{m}$ & All & 0.22 & 0.246 & -0.16 & 0.244 & -0.12 & 0.504 \\
\hline $250-1000 \mu \mathrm{m}$ & All & 0.02 & 0.23 & -0.21 & 0.228 & -0.25 & 0.272 \\
\hline $53-250 \mu \mathrm{m}$ & All & -0.21 & 0.261 & -0.30 & 0.263 & -0.16 & 0.150 \\
\hline
\end{tabular}

dynamics of coarse POM, whereas clay was considered significant for controlling the fine POM fraction. The BD was a significant predictor for all POM fractions except for the POM-N > $1000 \mu \mathrm{m}$. However, the effect of $\mathrm{BD}$ on POM was usually temporally variable and independent of tillage. Although tillage affected $\mathrm{BD}$ as much as POM and its stocks were significantly related to $\mathrm{BD}$, little is known about the mechanisms relating $\mathrm{BD}$ and soil POM$\mathrm{C}$ and $-\mathrm{N}$ pools. Moreover, the control of clay or $\mathrm{BD}$ on coarse POM tended to vary greatly with time, probably due to the confounding effects of tillage and temporally variable factors, such as soil water. However, the relationship between fine POM and clay or BD was irrespective of field or sampling time, suggesting dominant tillage effects that are not significantly influenced by the spatiotemporal variation of other biophysical factors. In conclusion, in a typical California farming system, reduced tillage may not necessarily lead to soil $\mathrm{C}$ increase compared to ST but maintain the level of soil C. In addition, clay content and BD were identified as key factors influencing the spatiotemporal variability of POM.

\section{Acknowledgments}

This work was funded by the Kearney Foundation of Soil Science, Project no. 2005.204. The authors thank Amy P. King, Jeannie Evatt, Jessica Louie, Antonio Orozco, Hyuisun Yoo, George Lu, Emily Sharp, and Mia Jung for soil sampling and laboratory assistance. They also thank Jan Willem van Groenigen for discussion on spatial data analysis.

\section{References}

[1] J. Six, R. T. Conant, E. A. Paul, and K. Paustian, "Stabilization mechanisms of soil organic matter: implications for Csaturation of soils," Plant and Soil, vol. 241, no. 2, pp. 155-176, 2002.

[2] S. M. Ogle, F. J. Breidt, and K. Paustian, "Agricultural management impacts on soil organic carbon storage under moist and dry climatic conditions of temperate and tropical regions," Biogeochemistry, vol. 72, no. 1, pp. 87-121, 2005.

[3] K. Paustian, J. Six, E. T. Elliott, and H. W. Hunt, "Management options for reducing CO emissions from agricultural soils," Biogeochemistry, vol. 48, no. 1, pp. 147-163, 2000.

[4] O. Oenema, G. Velthof, and P. Kuikman, "Technical and policy aspects of strategies to decrease greenhouse gas emissions from agriculture," Nutrient Cycling in Agroecosystems, vol. 60, no. 13, pp. 301-315, 2001.

[5] A. J. Franzluebbers, F. M. Hons, and D. A. Zuberer, "Tillageinduced seasonal changes in soil physical properties affecting soil CO evolution under intensive cropping," Soil and Tillage Research, vol. 34, no. 1, pp. 41-60, 1995.

[6] R. L. Desjardins, S. N. Kulshreshtha, B. Junkins, W. Smith, B. Grant, and M. Boehm, "Canadian greenhouse gas mitigation options in agriculture," Nutrient Cycling in Agroecosystems, vol. 60, no. 1-3, pp. 317-326, 2001.

[7] C. A. Cambardella, T. B. Moorman, J. M. Novak, et al., "Fieldscale variability of soil properties in central Iowa soils," Soil Science Society of America Journal, vol. 58, no. 5, pp. 15011511, 1994.

[8] S. H. Hurlbert, "Pseudoreplication and the design of ecological field experiments," Ecological Monographs, vol. 54, pp. 187211, 1984. 
[9] N. T. Hobbs, "Challenges and opportunities in integrating ecological knowledge across scales," Forest Ecology and Management, vol. 181, no. 1-2, pp. 223-238, 2003.

[10] W. W. Hargrove and J. Pickering, "Pseudoreplication: a sine qua non for regional ecology," Landscape Ecology, vol. 6, no. 4, pp. 251-258, 1992.

[11] L. Oksanen, "Logic of experiments in ecology: is pseudoreplication a pseudoissue?" Oikos, vol. 94, no. 1, pp. 27-38, 2001.

[12] R. E. Plant, "Comparison of means of spatial data in unreplicated field trials," Agronomy Journal, vol. 99, no. 2, pp. 481-488, 2007.

[13] F. C. Stevenson, J. D. Knight, O. Wendroth, C. van Kessel, and D. R. Nielsen, "A comparison of two methods to predict the landscape-scale variation of crop yield," Soil and Tillage Research, vol. 58, no. 3-4, pp. 163-181, 2001.

[14] A. Stewart-Oaten, W. W. Murdoch, and K. R. Parker, "Environmental impact assessment: "pseudoreplication" in time?" Ecology, vol. 67, no. 4, pp. 929-940, 1986.

[15] E. P. Smith, "BACI design," in Encyclopedia of Environmetrics, A. H. El-Shaarawi and W. W. Piegorsch, Eds., pp. 141-148, John Wiley \& Sons, New York, NY, USA, 2002.

[16] A. J. Underwood, "Beyond BACI: experimental designs for detecting human environmental impacts on temporal variations in natural populations," Australian Journal of Marine \& Freshwater Research, vol. 42, no. 5, pp. 569-587, 1991.

[17] A. J. Underwood, "Beyond BACI: the detection of environmental impacts on populations in the real, but variable, world," Journal of Experimental Marine Biology and Ecology, vol. 161, no. 2, pp. 145-178, 1992.

[18] A. J. Underwood, "On beyond BACI: sampling designs that might reliably detect environmental disturbances," Ecological Applications, vol. 4, no. 1, pp. 3-15, 1994.

[19] A. Stewart-Oaten and P. A. Murtaugh, "On rejection rates of paired intervention analysis: comment," Ecology, vol. 84, no. 10, pp. 2795-2802, 2003.

[20] C. van Kessel, R. E. Farrell, and D. J. Pennock, "Variations of carbon-13 and nitrogen-15 natural abundance in crop resides and soil organic matter," Soil Science Society of America Journal, vol. 58, pp. 382-389, 1994.

[21] B. A. Hungate, R. B. Jackson, C. B. Field, and F. S. Chapin III, "Detecting changes in soil carbon in $\mathrm{CO}_{2}$ enrichment experiments," Plant and Soil, vol. 187, no. 2, pp. 135-145, 1996.

[22] C. A. Cambardella and E. T. Elliot, "Particulate soil organicmatter changes across a grassland cultivation sequence," Soil Science Society of America Journal, vol. 56, no. 3, pp. 777-783, 1992.

[23] J. Six, E. T. Elliott, K. Paustian, and J. W. Doran, "Aggregation and soil organic matter accumulation in cultivated and native grassland soils," Soil Science Society of America Journal, vol. 62, no. 5, pp. 1367-1377, 1998.

[24] E. Besnard, C. Chenu, J. Balesdent, P. Puget, and D. Arrouays, "Fate of particulate organic matter in soil aggregates during cultivation," European Journal of Soil Science, vol. 47, no. 4, pp. 495-503, 1996.

[25] B. A. Needelman, M. M. Wander, G. A. Bollero, C. W. Boast, G. K. Sims, and D. G. Bullock, "Interaction of tillage and soil texture: biologically active soil organic matter in Illinois," Soil Science Society of America Journal, vol. 63, pp. 1326-1334, 1999.

[26] T. O. West and W. M. Post, "Soil organic carbon sequestration rates by tillage and crop rotation: a global data analysis," Soil Science Society of America Journal, vol. 66, no. 6, pp. 19301946, 2002.
[27] M. D. Eve, M. Sperow, K. Howerton, K. Paustian, and R. F. Follet, "Predicted impact of management changes on soil carbon stocks for each agricultural region of the conterminous United States," Journal of Soil and Water Conservation, vol. 57, pp. 196-204, 2002.

[28] Soil Conservation Service, "Soil survey of Yolo county, California," Soil conservation service in cooperation with university of California agricultural experiment station. USDA, Washington, DC, USA, 1972.

[29] J. P. Mitchell, K. Klonsky, A. Shrestha, et al., "Adoption of conservation tillage in California: current status and future perspectives," Australian Journal of Experimental Agriculture, vol. 47, no. 12, pp. 1383-1388, 2007.

[30] G. Eshel, G. J. Levy, U. Mingelgrin, and M. J. Singer, "Critical evaluation of the use of laser diffraction for particle-size distribution analysis," Soil Science Society of America Journal, vol. 68, no. 3, pp. 736-743, 2004.

[31] B. H. Ellert and J. R. Bettany, "Calculation of organic matter and nutrients stored in soils under contrasting management regimes," Canadian Journal of Soil Science, vol. 75, no. 4, pp. 529-538, 1995.

[32] C. C. Cerri, J. Feller, R. Balesdent, R. L. Victoria, and A. Plenecassagne, "Application du traçage isotopique naturel in ${ }^{13} \mathrm{C}$ à l'étude de la dynamique de la matière organique dans les sols," Comptes Rendus de l'Académie des Sciences, vol. 300, pp. 423-428, 1985.

[33] R. B. D'Agostino, A. Belanger, and R. B. D'Agostino Jr., "A suggestion for using powerful and informative tests of normality," Journal of the American Statistical Association, vol. 44, pp. 316-321, 1990.

[34] SAS Institute, "SAS/STAT User's Guide," SAS Institute Inc., Cary, NC, USA, 2004.

[35] W. Mendenhall and T. Sincich, Statistics for Engineering and the Sciences, Prentice Hall, Englewood Cliffs, NJ, USA, 4th edition, 1995.

[36] E. H. Isaaks and R. M. Srivastava, An Introduction to Applied Geostatistics, Oxford University Press, New York, NY, USA, 1989.

[37] J. C. Pinheiro and D. M. Bates, Mixed-Effects Models in S and S-PLUS, Springer, New York, NY, USA, 2000.

[38] H. Blanco-Canqui, C. J. Gantzer, S. H. Anderson, and E. E. Alberts, "Tillage and crop influences on physical properties for an Epiaqualf," Soil Science Society of America Journal, vol. 68, no. 2, pp. 567-576, 2004.

[39] A. P. da Silva, B. D. Kay, and E. Perfect, "Management versus inherent soil properties effects on bulk density and relative compaction," Soil and Tillage Research, vol. 44, no. 1-2, pp. 8193, 1997.

[40] M. M. Wander, M. G. Bidart, and S. Aref, "Tillage impacts on depth distribution of total and particulate organic matter in three Illinois soils," Soil Science Society of America Journal, vol. 62, no. 6, pp. 1704-1711, 1998.

[41] S. D. Logsdon and C. A. Cambardella, "Temporal changes in small depth-incremental soil bulk density," Soil Science Society of America Journal, vol. 64, no. 2, pp. 710-714, 2000.

[42] P. W. Unger and D. K. Cassel, "Tillage implement disturbance effects on soil properties related to soil and water conservation: a literature review," Soil and Tillage Research, vol. 19, no. 4, pp. 363-382, 1991.

[43] J. Lee, J. Six, A. P. King, C. van Kessel, and D. E. Rolston, "Tillage and field scale controls on greenhouse gas emissions," Journal of Environmental Quality, vol. 35, no. 3, pp. 714-725, 2006. 
[44] J. M. Rey-Benayas, M. G. Sánchez-Colomer, and A. Escudero, "Landscape- and field-scale control of spatial variation of soil properties in Mediterranean mountane meadows," Biogeochemistry, vol. 69, pp. 207-225, 2004.

[45] E. A. Davidson, L. V. Verchot, J. Henrique Cattânio, I. L. Ackerman, and J. E. M. Carvalho, "Effects of soil water content on soil respiration in forests and cattle pastures of eastern Amazonia," Biogeochemistry, vol. 48, no. 1, pp. 53-69, 2000.

[46] D. C. Reicosky, D. W. Reeves, S. A. Prior, G. B. Runion, H. H. Rogers, and R. L. Raper, "Effects of residue management and controlled traffic on carbon dioxide and water loss," Soil and Tillage Research, vol. 52, no. 3-4, pp. 153-165, 1999.

[47] H. J. Farahani, G. A. Peterson, D. G. Westfall, L. A. Sherrod, and L. R. Ahuja, "Soil water storage in dryland cropping systems: the significance of cropping intensification," Soil Science Society of America Journal, vol. 62, no. 4, pp. 984-991, 1998.

[48] G. A. Peterson, A. J. Schlegel, D. L. Tanaka, and O. R. Jones, "Precipitation use efficiency as affected by cropping and tillage systems," Journal of Production Agriculture, vol. 9, no. 2, pp. 180-186, 1996.

[49] A. J. Franzluebbers and M. A. Arshad, "Particulate organic carbon content and potential mineralization as affected by tillage and texture," Soil Science Society of America Journal, vol. 61, no. 5, pp. 1382-1386, 1997.

[50] K. Y. Chan, "Soil particulate organic carbon under different land use and management," Soil Use and Management, vol. 17, no. 4, pp. 217-221, 2001.

[51] J. Six, E. T. Elliott, and K. Paustian, "Aggregate and soil organic matter dynamics under conventional and no-tillage systems," Soil Science Society of America Journal, vol. 63, no. 5, pp. 13501358, 1999.

[52] J. D. Jastrow, "Soil aggregate formation and the accrual of particulate and mineral-associated organic matter," Soil Biology and Biochemistry, vol. 28, no. 4-5, pp. 665-676, 1996.

[53] G. D. Schwenke, W. L. Felton, D. F. Herridge, D. F. Khan, and M. B. Peoples, "Relating particulate organic matter-nitrogen (POM-N) and non-POM-N with pulse crop residues, residue management and cereal N uptake," Agronomie, vol. 22, no. 7-8, pp. 777-787, 2002.

[54] K. Y. Chan, "Consequences of changes in particulate organic carbon in Vertisols under pasture and cropping," Soil Science Society of America Journal, vol. 61, no. 5, pp. 1376-1382, 1997.

[55] J. Hassink, "The capacity of soils to preserve organic C and N by their association with clay and silt particles," Plant and Soil, vol. 191, no. 1, pp. 77-87, 1997.

[56] M. M. Wander and M. G. Bidart, "Tillage practice influences on the physical protection, bioavailability and composition of particulate organic matter," Biology and Fertility of Soils, vol. 32, no. 5, pp. 360-367, 2000.

[57] B. C. Ball, D. J. Campbell, and E. A. Hunter, "Soil compactibility in relation to physical and organic properties at 156 sites in UK," Soil and Tillage Research, vol. 57, no. 1-2, pp. 83-91, 2000. 

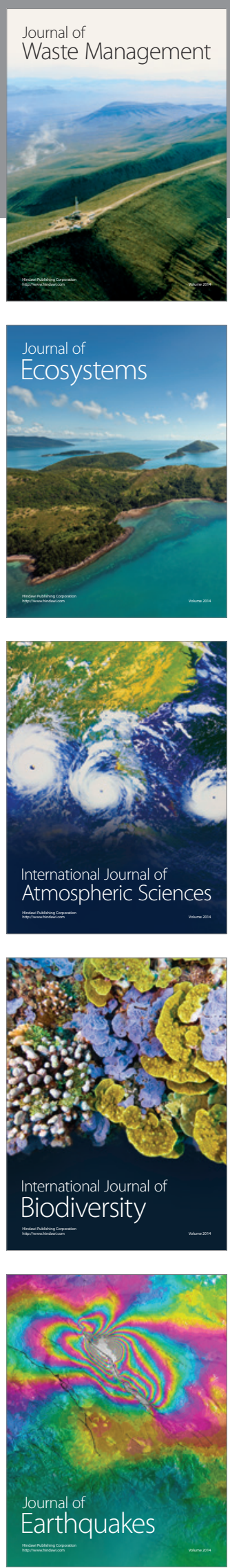
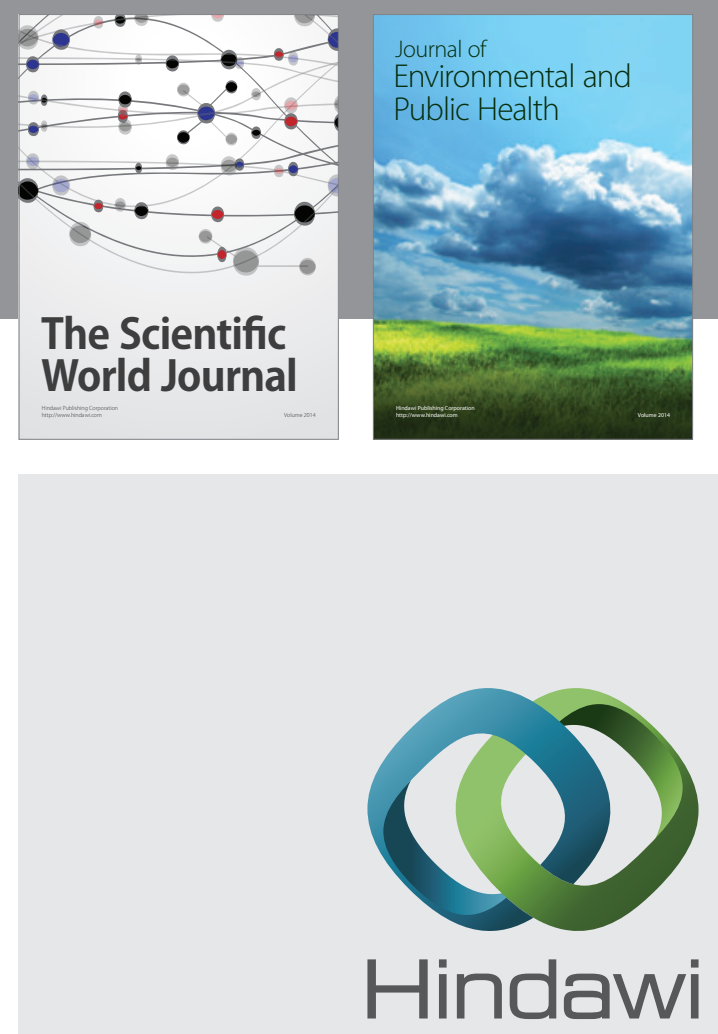

Submit your manuscripts at

http://www.hindawi.com
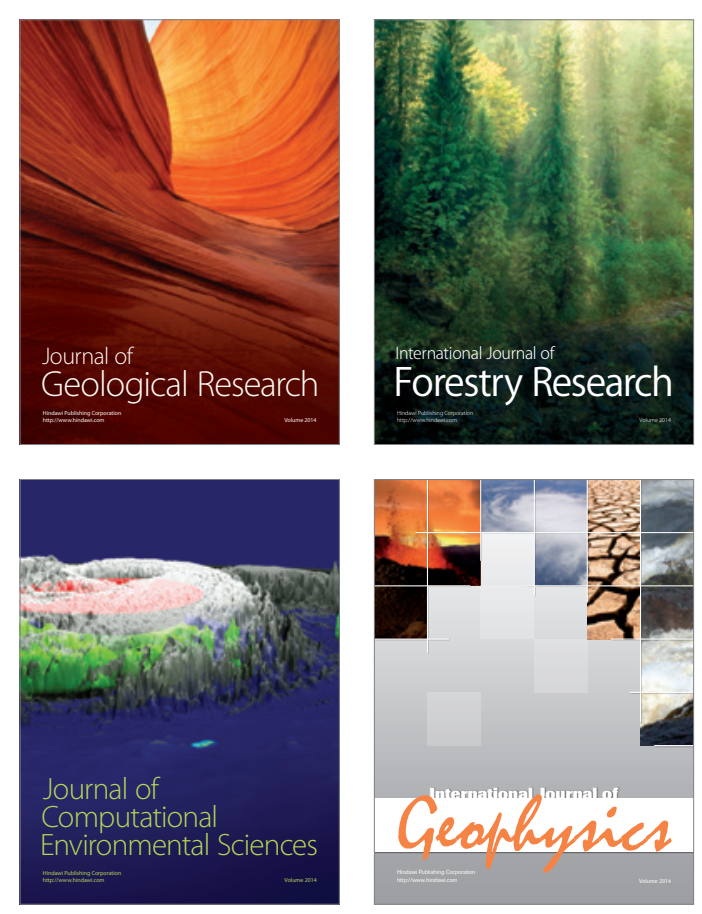
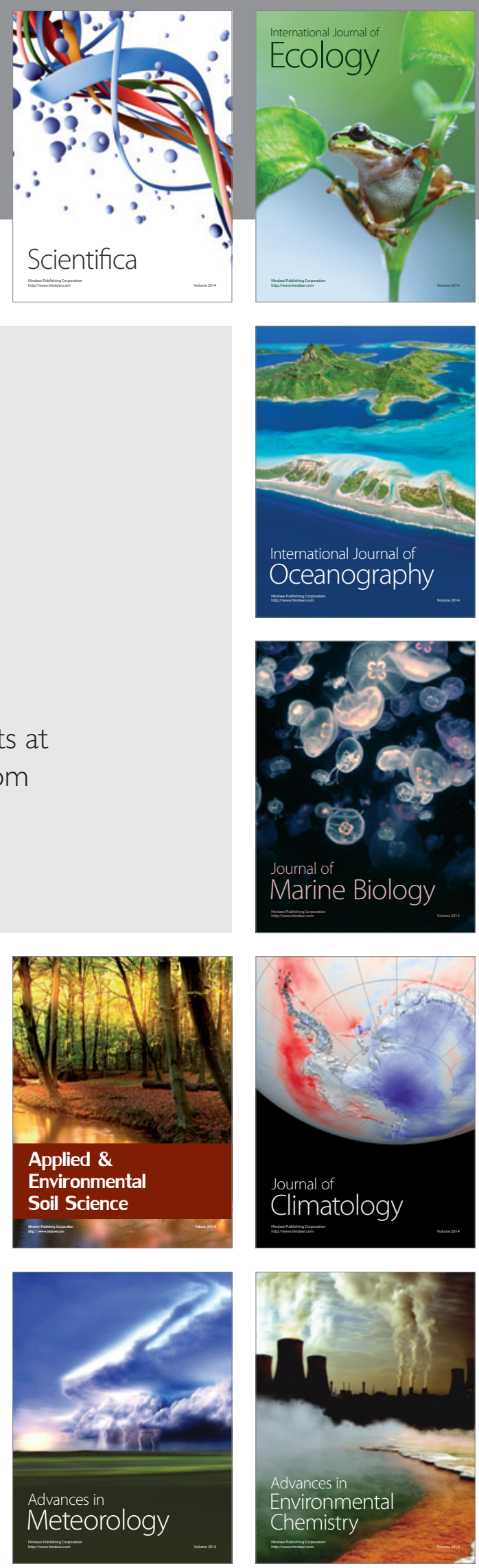